\title{
Kacper Millkowski
}

Uniwersytet Warmińsko-Mazurski w Olsztynie

ORCID ID: 0000-0003-4367-0365

\section{PRZEGLAD ORZZECZNICTWA SĄDU NÁJWYŻSZEGO}

\section{ABSTRACT}

\section{Overview of the decisions of the Polish Supreme Court}

The resolution of the panel of seven judges of the Polish Supreme Court of November 9, 2021 (case file no. I KZP 5/21) is of utmost importance for legal practice. In the resolution, the Polish Supreme Court assumed that a witness who gives false testimony out of fear of criminal liability shall not be subject to the offense under Article $233 \$$ la of the Polish Penal Code if, in exercising their right to defense, they testify untruthfully or conceal the truth without at the same time exhausting the qualities of the offense defined in another provision of the aforementioned act. The Polish Supreme Court decided to make the resolution a legal principle. Another important resolution of the Polish Supreme Court is the resolution of the panel of seven judges of January 14, 2022 (case file no. III CZP 7/22). As indicated by the Supreme Court, the liability of

1 Doktorant w Katedrze Prawa Międzynarodowego Publicznego i Prawa Unii Europejskiej na Wydziale Prawa i Administracji na Uniwersytecie Warmińsko-Mazurskim w Olsztynie. 
the insurance company resulting from the contract of a compulsory third party liability insurance of motor vehicle owners covers damages caused as a result of the operation of the device installed in the vehicle, even if the vehicle did not fulfill the communication function at the time of the damage. However, in accordance with the resolution of the panel of seven judges of the Polish Supreme Court of December 8, 2021 (case file no. III CZP 83/20) - a correction of a press material may be signed by the attorney of the person interested in its publication (Article 31a (1) and (4) of the Polish Press Law Act).

Keywords: Supreme Court, judicature, criminal proceedings, civil proceedings, witness, compensation for damage, statute of limitations, press law

Słowa kluczowe: Sąd Najwyższy, orzecznictwo, postępowanie karne, postępowanie cywilne, świadek, naprawienie szkody, przedawnienie, prawo prasowe

\section{Sprawy z zakresu prawa cywilnego i gospodarczego}

\section{Uchwała składu siedmiu sędziów Sądu Najwyższego z 14 stycznia 2022 r., III CZP 7/22}

Odpowiedzialność zakładu ubezpieczeń wynikająca z umowy obowiązkowego ubezpieczenia odpowiedzialności cywilnej posiadaczy pojazdów mechanicznych obejmuje szkody wyrządzone w wyniku pracy urządzenia zamontowanego w pojeździe także wtedy, gdy w chwili wyrządzenia szkody pojazd nie pełnił funkcji komunikacyjnej (art. 34 ustawy z 22 maja 2003 r. o ubezpieczeniach obowiązkowych, Ubezpieczeniowym Funduszu Gwarancyjnym i Polskim Biurze Ubezpieczycieli Komunikacyjnych t.j. Dz.U. z 2021 r. poz. 854 w związku z art. 436 k.c.).

Uchwała składu siedmiu sędziów Sądu Najwyższego z 16 grudnia 2021 r., III CZP 99/20

Sąd apelacyjny lub sąd okręgowy jako sąd odwoławczy, stwierdzając przy rozpoznaniu sprawy oczywistą obrazę przepisów, poucza sędziego, asesora sądowego, wchodzących w skład sądu orzekającego, o możliwości złożenia na piśmie wyjaśnień (art. $40 \$ 1$ ustawy z 27 lipca 2001 r. - Prawo o ustroju sądów powszechnych; t.j. Dz.U. z 2020 r. poz. 2072 ze zm.) w dniu wydania orzeczenia. Postanowienie zawierające wytknięcie 
uchybienia powinno być wydane niezwłocznie po złożeniu wyjaśnień lub upływie terminu do ich złożenia.

Uchwała składu siedmiu sędziów Sądu Najwyższego z 16 grudnia 2021 r., III CZP 98/20

Sąd apelacyjny lub sąd okręgowy jako sąd odwoławczy wytyka uchybienie właściwemu sądowi na podstawie art. 40 \$ 1 ustawy z 27 lipca 2001 r. - Prawo o ustroju sądów powszechnych (t.j. Dz.U. z 2020 r. poz. 2072 ze zm.) w tym samym składzie, w którym rozpoznał sprawę.

Uchwała składu siedmiu sędziów Sądu Najwyższego z 8 grudnia 2021 r., III CZP 83/20

Sprostowanie materiału prasowego może być podpisane przez pełnomocnika osoby zainteresowanej jego opublikowaniem (art. 31a ust. 1 i 4 ustawy z 26 stycznia 1984 r. - Prawo prasowe, t.j. Dz.U. z 2018 r. poz. 1914).

Uchwała składu siedmiu sędziów Sądu Najwyższego z 22 października 2021 r., III CZP 78/20

Przewidziany w art. 119 k.c. zakaz zmiany terminu przedawnienia roszczenia przez czynność prawną nie stoi na przeszkodzie odroczeniu przez strony terminu spełnienia świadczenia, choćby roszczenie stało się już wymagalne; w takim przypadku przedawnienie biegnie na nowo z upływem odroczonego terminu.

Uchwała Sądu Najwyższego z 28 stycznia 2022 r., III CZP 38/22

Od powoda będącego konsumentem, dochodzącego w jednym pozwie kilku roszczeń wynikających z czynności bankowych, pobiera się na podstawie art. 13a ustawy z 28 lipca 2005 r. o kosztach sądowych w sprawach cywilnych (t.j. Dz.U. z 2020 r. poz. 755 ze zm.) jedną opłatę stałą, jeżeli wartość przedmiotu sporu dla tych roszczeń, ustalona na podstawie art. 21 k.p.c., przewyższa kwotę 20 tys. zł.

Uchwała Sądu Najwyższego z 28 stycznia 2022 r., III CZP 35/22

Nabywca wierzytelności $\mathrm{w}$ drodze przelewu, na którego rzecz zasądzono koszty procesu, nie jest $\mathrm{w}$ tym zakresie wierzycielem pierwotnym 
w rozumieniu art. 29 ust. 5 pkt 3 lit. b z 28 lutego 2018 r. o kosztach komorniczych (t.j. Dz.U. z 2021 r. poz. 210 ze zm.).

\section{Uchwała Sądu Najwyższego z 28 stycznia 2022 r., III CZP 34/22}

Artykuł 29 ustawy z 28 lutego 2018 r. o kosztach komorniczych (t.j. Dz.U. z 2021 r. poz. 210 ze zm.) nie znajduje zastosowania, jeżeli sześciomiesięczny okres bezczynności wierzyciela, który nie zażądał podjęcia zawieszonego postępowania egzekucyjnego, upłynął przed dniem wejścia w życie tej ustawy, komornik zaś umorzył postępowanie z tej przyczyny na podstawie art. 824 \$ 1 pkt 4 k.p.c. po dniu 1 stycznia 2019 r.

\section{Uchwała Sądu Najwyższego z 28 stycznia 2022 r., III CZP 21/22}

Artykuł 30 ustawy z 28 lutego 2018 r. o kosztach komorniczych (t.j. Dz.U. z 2021 r. poz. 210 ze zm.) nie stanowi podstawy pobrania przez komornika sądowego opłaty egzekucyjnej od wierzyciela w przypadku umorzenia postępowania egzekucyjnego na podstawie art. $824 \$ 1$ pkt 2 k.p.c. ze względu na złożenie przez wierzyciela wniosku o wszczęcie postępowania egzekucyjnego po ogłoszeniu upadłości dłużnika.

\section{Uchwała Sądu Najwyższego z 28 stycznia 2022 r., III CZP 19/22}

Nieruchomość, której właścicielowi przysługuje wynikające z art. 4 ust. 4 oraz 241 ust. 6 ustawy z 15 grudnia 2000 r. o spółdzielniach mieszkaniowych (t.j. Dz.U. z 2021 r. poz. 1208) uprawnienie do korzystania $\mathrm{z}$ dróg wewnętrznych łączących się z drogą publiczną, ma odpowiedni dostęp do drogi publicznej w rozumieniu art. $145 \$ 1$ k.c.

\section{Uchwała Sądu Najwyższego z 27 stycznia 2022 r., III CZP 36/22}

Złożenie przez wierzyciela wniosku egzekucyjnego przeciwko zmarłemu dłużnikowi stanowi oczywiście niecelowe wszczęcie postępowania egzekucyjnego w rozumieniu art. 30 ustawy z 28 lutego 2018 r. o kosztach komorniczych.

\section{Uchwała Sądu Najwyższego z 25 stycznia 2022 r., III CZP 51/22}

Na postanowienie sądu pierwszej instancji co do składu grupy wydane $\mathrm{w}$ postępowaniu grupowym przysługuje zażalenie do sądu drugiej instancji (art. 394 k.p.c. w zw. z art. 24 ust. 1 ustawy z 17 grudnia 2009 r. 
o dochodzeniu roszczeń w postępowaniu grupowym, t.j. Dz.U. z 2020 r. poz. 446 ze zm.).

\section{Uchwała Sądu Najwyższego z 25 stycznia 2022 r., III CZP 4/22}

Postępowanie wywołane zażaleniem na postanowienie sądu pierwszej instancji w przedmiocie zabezpieczenia umarza sąd, który wydał zaskarżone postanowienie, w składzie trzech sędziów (art. $741 \$ 2$ k.p.c.).

\section{Uchwała Sądu Najwyższego z 21 stycznia 2022 r., III CZP 58/22}

Sąd opiekuńczy, orzekając o zleceniu kuratorowi sądowemu przymusowego odebrania osoby podlegającej władzy rodzicielskiej (art. 598 k.p.c.), nie bada zasadności orzeczenia podlegającego wykonaniu.

\section{Uchwała Sądu Najwyższego z 21 stycznia 2022 r., III CZP 37/22}

Na postanowienie sądu pierwszej instancji w przedmiocie wynagrodzenia kuratora strony, której miejsce pobytu nie jest znane, przysługuje zażalenie do innego składu tego sądu (art. $394^{\text {la }} \$ 1$ pkt 9 k.p.c. per analogiam). Jeżeli kuratorem takim jest adwokat, jego wynagrodzenie podlega podwyższeniu o należny podatek od towarów i usług.

\section{Uchwała Sądu Najwyższego z 20 stycznia 2022 r., III CZP 30/22}

W sprawie z wniosku gminy o złożenie do depozytu sądowego należności podatkowej podlegającej zwrotowi, wskazującego na wątpliwości co do następstwa prawnego podmiotu, na którego rzecz ma nastąpić zwrot, droga sądowa jest dopuszczalna.

\section{Uchwała Sądu Najwyższego z 20 stycznia 2022 r., III CZP 23/22}

W sprawie o stwierdzenie zasiedzenia służebności przesyłu sąd nie jest związany ustaleniami i oceną prawną, które zadecydowały o prawomocnym oddaleniu wniosku o ustanowienie tej służebności w sprawie między tymi samymi uczestnikami z uwagi na uwzględnienie zarzutu jej zasiedzenia.

\section{Uchwała Sądu Najwyższego z 20 stycznia 2022 r., III CZP 17/22}

Nie jest dopuszczalne ustalenie na podstawie art. 189 k.p.c., że na walnym zgromadzeniu akcjonariuszy spółki akcyjnej została podjęta określona uchwała, jeżeli w protokole walnego zgromadzenia stwierdzono, że uchwała nie została podjęta. 
Uchwała Sądu Najwyższego z 20 stycznia 2022 r., III CZP 9/22

Sprawca wypadku komunikacyjnego i zakład ubezpieczeń, z którym sprawca wypadku jest związany umową ubezpieczenia odpowiedzialności cywilnej posiadaczy pojazdów mechanicznych za szkody związane $\mathrm{z}$ ruchem tych pojazdów, odpowiadają wobec zarządcy drogi za szkodę spowodowaną zanieczyszczeniami drogi płynami silnikowymi.

\section{Uchwała Sądu Najwyższego z 20 stycznia 2022 r., III CZP 8/22}

Nieważne jest postanowienie umowy o ustanowieniu użytkowania wieczystego określające obowiązek zapłaty przez użytkownika wieczystego kary umownej w wypadku niezagospodarowania nieruchomości w terminie wskazanym $w$ umowie.

\section{Uchwała Sądu Najwyższego z 13 stycznia 2022 r., III CZP 65/22}

Na podstawie art. $754^{1} \$ 2$ k.p.c. w zw. $z$ art. $754^{1} \$ 1$ k.p.c. dopuszczalna jest zmiana terminu upadku zabezpieczenia przez zajęcie wierzytelności $\mathrm{z}$ rachunku bankowego (art. 747 pkt 1 k.p.c.) postanowieniem wydanym przez sąd po upływie miesięcznego terminu od uprawomocnienia się orzeczenia uwzględniającego roszczenie, jeśli uprawniony złożył wniosek o zmianę terminu przed jego uplywem.

\section{Uchwała Sądu Najwyższego z 13 stycznia 2022 r., III CZP 61/22}

Początek biegu terminu przedawnienia roszczenia konsumenta będącego ubezpieczonym lub ubezpieczającym z tytułu zwrotu świadczenia nienależnego, związanego z pobraniem przez ubezpieczyciela $\mathrm{w}$ trakcie trwania umowy ubezpieczenia na życie z ubezpieczeniowym funduszem kapitałowym opłat niestanowiących kosztów udzielonej ochrony ubezpieczeniowej, na podstawie niedozwolonych postanowień umownych (art. $385^{1}$ k.c.), nie może rozpocząć się, zanim konsument dowiedział się lub, rozsądnie rzecz ujmując, powinien dowiedzieć się o niedozwolonym charakterze postanowienia.

\section{Uchwała Sądu Najwyższego z 13 stycznia 2022 r., III CZP 14/22}

Po podziale nieruchomości władnącej, a następnie scaleniu wydzielonej w ten sposób części z inną nieruchomością, niemającą statusu nieruchomości władnącej, służebność gruntowa rozciąga się na całą powstałą w ten sposób nieruchomość. 
Uchwała Sądu Najwyższego z 12 stycznia 2022 r., III CZP 78/22

Jeżeli naruszenie zakazu konkurencji, o którym mowa w art. $56 \$ 2$ k.s.h., polega na podjęciu dających się zindywidualizować, powtarzających się zachowań, roszczenia wspólnika przewidziane w art. $57 \$ 1$ k.s.h. przedawniają się z uplywem sześciu miesięcy od dnia, gdy wszyscy pozostali wspólnicy dowiedzieli się o naruszeniu zakazu, nie później jednak niż $\mathrm{z}$ upływem trzech lat (art. $57 \$ 2$ k.s.h.), liczonych odrębnie w stosunku do każdego zachowania.

\section{Uchwała Sądu Najwyższego z 12 stycznia 2022 r., III CZP 67/22}

Zawarcie przez spółkę akcyjną umowy poręczenia za dług małżonka, pozostającego z członkiem zarządu tej spółki w ustroju wspólności ustawowej, wymaga zgody walnego zgromadzenia (art. $15 \$ 1$ k.s.h.).

\section{Uchwała Sądu Najwyższego z 12 stycznia 2022 r., III CZP 60/22}

$\mathrm{W}$ sprawie o pozbawienie wykonalności tytułu wykonawczego strona pozwana, która na jego podstawie jest uprawniona do egzekwowania należnych jej świadczeń alimentacyjnych, jest ustawowo zwolniona od kosztów sądowych na podstawie art. 96 ust. 1 pkt 2 ustawy z 28 lipca 2005 r. o kosztach sądowych w sprawach cywilnych.

\section{Uchwała Sądu Najwyższego z 12 stycznia 2022 r., III CZP 24/22}

Do umowy przelewu wierzytelności zawartej między dwiema spółkami z ograniczoną odpowiedzialnością, przy której zawarciu jedną z nich reprezentuje pełnomocnik ustanowiony przez członka jednoosobowego zarządu, który to członek zarząa jest jednocześnie prokurentem samoistnym drugiej spółki, ma zastosowanie art. 108 k.c. w zw. z art. 2 k.s.h.

\section{Uchwała Sądu Najwyższego z 9 grudnia 2021 r., III CZP 112/20}

Upływ czasu od spełnienia świadczenia nie ma znaczenia dla możliwości żądania jego zwrotu przez osobę uchylającą się od skutków oświadczenia woli (art. $88 \rrbracket 1$ k.c.), w którym świadczenie to znajdowało podstawę.

\section{Uchwała Sądu Najwyższego z 9 grudnia 2021 r., III CZP 103/20}

Artykul 68 ust. 6 ustawy z 14 maja 2020 r. o zmianie niektórych ustaw $\mathrm{w}$ zakresie działań osłonowych $\mathrm{w}$ związku $\mathrm{z}$ rozprzestrzenianiem się 
wirusa SARS-CoV-2, przewidujący rozpoczęcie biegu terminów po upływie siedmiu dni od dnia wejścia w życie tej ustawy, odnosi się do terminów, które nie rozpoczęły biegu na podstawie art. 15zzs ustawy z 2 marca 2020 r. o szczególnych rozwiązaniach związanych z zapobieganiem, przeciwdziałaniem i zwalczaniem COVID-19, innych chorób zakaźnych oraz wywołanych nimi sytuacji kryzysowych, a nie do terminów, które zgodnie z zasadami ogólnymi rozpoczynają bieg po uchyleniu tego przepisu.

\section{Uchwała Sądu Najwyższego z 9 grudnia 2021 r., III CZP 96/20}

Dla wyczerpania trybu, o którym mowa w art. 145 ust. 1 ustawy z 28 lutego 2003 r. - Prawo upadłościowe i naprawcze, konieczne jest zaskarżenie odmowy uznania wierzytelności sprzeciwem do sędziego-komisarza, a w razie nieuwzględnienia sprzeciwu wniesienie zażalenia do sądu upadłościowego.

\section{Uchwała Sądu Najwyższego z 9 grudnia 2021 r., III CZP 85/20}

Roszczenie odszkodowawcze uzupełniające (art. 18 ust. 2 zdanie drugie ustawy z 21 czerwca 2001 r. o ochronie praw lokatorów, mieszkaniowym zasobie gminy i o zmianie Kodeksu cywilnego, t.j. Dz.U. z 2020 r. poz. 611 ze zm.), obejmujące opłaty niezależne od właściciela, dochodzone przez gminę przeciwko osobie zajmującej lokal bez tytułu prawnego za okres po ustaniu tego tytułu, nie jest związane z prowadzeniem działalności gospodarczej w rozumieniu art. 118 k.c.

\section{Uchwała Sądu Najwyższego z 9 grudnia 2021 r., III CZP 49/21}

W przypadku zaskarżenia postanowień sądu pierwszej instancji o odrzuceniu pozwu (art. 394 S 1 in principio k.p.c.) i w przedmiocie zabezpieczenia (art. $741 \S 1$ k.p.c.) zażalenie na pierwsze z tych postanowień podlega rozpoznaniu przez sąd drugiej instancji, a drugie - przez sąd, który wydał zaskarżone postanowienie. Dotyczy to również przypadku, w którym zaskarżone postanowienia zostały objęte jednym dokumentem, a zażalenia zawarto w jednym piśmie procesowym.

\section{Uchwała Sądu Najwyższego z 9 grudnia 2021 r., III CZP 26/21}

1. Dopuszczalne jest zastrzeżenie kary umownej na wypadek niewykonania albo nienależytego wykonania przez wierzyciela czynności, 
bez której świadczenie dłużnika w umowie o roboty budowlane nie może być spełnione.

2. Maksymalna wysokość kary umownej nie musi być wyrażona w kwocie pieniężnej; wystarczy, że można ją oznaczyć na podstawie umowy i w świetle okoliczności sprawy.

Uchwała Sądu Najwyższego z 9 grudnia 2021 r., III CZP 21/21

$\mathrm{Na}$ żądanie dłużnika sąd postanowi o zwrocie depozytu sądowego (art. $469 \$ 1$ k.c.), chyba że przed lub równocześnie ze złożeniem wniosku przez dłużnika zostało złożone do sądu żądanie wierzyciela wydania mu depozytu (art. $693^{11} \$ 1-2$ k.p.c.).

\section{Uchwała Sądu Najwyższego z 9 grudnia 2021 r., III CZP 16/21}

Dopuszczalne jest zastrzeżenie kary umownej za zwłokę w wykonaniu zobowiązania w postaci określonego procentu ustalonego wynagrodzenia umownego za każdy dzień zwłoki, nawet jeżeli nie określono końcowego terminu naliczania kary umownej ani jej kwoty maksymalnej.

\section{Uchwała Sądu Najwyższego z 7 grudnia 2021 r., III CZP 87/20}

Zażalenie na postanowienie sądu pierwszej instancji $\mathrm{w}$ postępowaniu egzekucyjnym odrzuca sąd, który wydał zaskarżone postanowienie, w składzie trzech sędziów (art. $767^{4} \$ 1^{1}$ k.p.c.).

\section{Uchwała Sądu Najwyższego z 7 grudnia 2021 r., III CZP 67/20}

Sąd opiekuńczy może - na podstawie art. 67 ust. 1 ustawy z 28 listopada 2014 r. - Prawo o aktach stanu cywilnego (t.j. Dz.U. z 2021 r. poz. 709) postanowić o sporządzeniu nowego aktu urodzenia po prawomocnym zaprzeczeniu ojcostwa męża matki. Zainteresowanym w takiej sprawie jest także mężczyzna, którego ojcostwo zostało zaprzeczone (art. 510 $\$ 1$ k.p.c.). Jeżeli okaże się, że nie jest on uczestnikiem postępowania, sąd wezwie go do udziału w sprawie (art. $510 \$ 2$ k.p.c.).

\section{Uchwała Sądu Najwyższego z 3 grudnia 2021 r., III CZP 90/20}

Zgodnie z art. 376 ust. 1 ustawy z 28 lutego 2003 r. - Prawo upadłościowe (t.j. Dz.U. z 2020 r. poz. 1228) zarządca przymusowy ustanowiony na podstawie art. $1064^{10}$ k.p.c. nie jest uprawniony do złożenia wniosku 
o orzeczenie zakazu prowadzenia działalności gospodarczej, o którym mowa w art. 373 ustawy - Prawo upadłościowe.

\section{Uchwała Sądu Najwyższego z 3 grudnia 2021 r., III CZP 84/20}

Prawomocny wyrok zasądzający z urzędu w postępowaniu karnym zadośćuczynienie na rzecz pokrzywdzonego (art. $46 \$ 1$ k.k.) nie stwarza powagi rzeczy osądzonej w części, w której zadośćuczynienie nie zostało zasądzone (art. $46 \$ 3$ k.k. i art. $415 \$ 2$ k.p.k.).

\section{Uchwała Sądu Najwyższego z 24 listopada 2021 r., III CZP 80/20}

Na postanowienie referendarza sądowego o odmowie zwolnienia od opłaty od apelacji, wydane w sądzie drugiej instancji, przysługuje skarga.

\section{Uchwała Sądu Najwyższego z 18 listopada 2021 r., III CZP 77/20}

Uprawomocnienie się postanowienia o ogłoszeniu upadłości dłużnika (art. 146 ust. 1 zdanie drugie ustawy z 28 lutego 2003 r. - Prawo upadłościowe, t.j. Dz.U. z 2020 r. poz. 1228 ze zm.) nie jest przeszkodą do przysądzenia własności nieruchomości na rzecz nabywcy licytacyjnego, któremu prawomocnie udzielono przybicia przed ogłoszeniem upadłości dłużnika i który wykonał warunki licytacyjne (art. 998 \& 1 k.p.c.).

\section{Postanowienie Sądu Najwyższego z 18 listopada 2021 r., V CO 209/21}

Stosownie do art. $45 \$ 1$ k.p.c., jeżeli na podstawie przepisów kodeksu nie można w świetle okoliczności sprawy ustalić właściwości miejscowej, Sąd Najwyższy oznaczy sąd, przed który należy wytoczyć powództwo. Oznaczenie przez Sąd Najwyższy sądu właściwego do rozpoznania sprawy o rozwód jest więc uzasadnione dopiero $w$ razie stwierdzenia, że żadna ze stron nie ma miejsca zamieszkania na terytorium Rzeczpospolitej Polskiej i nie jest możliwe ustalenie właściwości miejscowej sądu na podstawie art. 41 k.p.c.

\section{Uchwała Sądu Najwyższego z 16 listopada 2021 r., III CZP 76/20}

W stanie prawnym wprowadzonym od 7 listopada 2019 r. ustawą z 4 lipca 2019 r. o zmianie ustawy - Kodeks postępowania cywilnego oraz niektórych innych ustaw (Dz.U. z 2019 r. poz. 1496 ze zm.) sąd drugiej instancji rozpoznaje zażalenie na orzeczenie wydane przez sąd pierwszej instancji w sprawie toczącej się w postępowaniu uproszczonym w składzie jednego sędziego. 
Uchwała Sądu Najwyższego z 9 listopada 2021 r., III CZP 70/20

Dopuszczalna jest apelacja powoda od wyroku w części, w której oddalono jego żądanie główne w sytuacji, w której wyrok ten nie został zaskarżony w części uwzględniającej żądanie ewentualne.

\section{Uchwała Sądu Najwyższego z 9 listopada 2021 r., III CZP 69/20}

Do rozpoznania zażalenia na zarządzenie przewodniczącego o zwrocie wniosku o udzielenie zabezpieczenia w sądzie pierwszej instancji, wniesionego po 7 listopada 2019 r., właściwy jest sąd, w którym wydano zaskarżone zarządzenie (art. $741 \rrbracket 2$ k.p.c.).

\section{Uchwała Sądu Najwyższego z 5 listopada 2021 r., III CZP 68/20}

1. Zażalenie na postanowienie sądu pierwszej instancji, wniesione po 6 listopada 2019 r., którego przedmiotem jest wynagrodzenie kuratora, rozpoznaje inny skład sądu pierwszej instancji (art. 394 $\$ 1$ pkt 9 k.p.c. per analogiam), także w sprawach, w których przed dniem wejścia w życie ustawy z 4 lipca 2019 r. o zmianie ustawy - Kodeks postępowania cywilnego oraz niektórych innych ustaw (Dz.U. z 2019 r. poz. 1469 ze zm.) wydano nakaz zapłaty w postępowaniu upominawczym.

2. Wynagrodzenie kuratora procesowego ustanowionego na podstawie art. $69 \rrbracket 1$ k.p.c., obowiązanego do rozliczenia podatku od towarów i usług, sąd podwyższa o kwotę tego podatku.

\section{Uchwała Sądu Najwyższego z 29 października 2021 r., III CZP 60/20}

Zarządzenie o zwrocie pozwu wniesionego przez adwokata, radcę prawnego, rzecznika patentowego lub Prokuratorię Generalną Rzeczypospolitej Polskiej, wydane na podstawie art. $130^{1 \mathrm{la}} \$ 1$ i 2 k.p.c., doręcza się tym podmiotom; termin do wniesienia zażalenia na to zarządzenie biegnie od dnia jego doręczenia z uzasadnieniem sporządzonym na żądanie, o którym mowa w art. 357 \$ 21 w związku z art. 362 k.p.c.

\section{Uchwała Sądu Najwyższego z 27 października 2021 r., III CZP 56/20}

$\mathrm{W}$ stanie prawnym obowiązującym przed zmianą art. 95 ustawy z 29 sierpnia 1997 r. - Prawo bankowe, dokonaną ustawą z 17 stycznia 2019 r. o zmianie ustawy o Bankowym Funduszu Gwarancyjnym, systemie gwarantowania depozytów oraz przymusowej restrukturyzacji oraz niektórych innych ustaw (Dz.U. z 2019 r. poz. 326) ujawnienie w księdze wieczystej 
przeniesienia hipoteki w związku ze zbyciem wierzytelności bankowej wymagało zgody właściciela nieruchomości tylko wtedy, gdy przewidziano ją w oświadczeniu o ustanowieniu hipoteki.

\section{Uchwała Sądu Najwyższego z 27 października 2021 r., III CZP 54/20}

Powołanie osoby fizycznej na funkcje kuratora wbrew jej woli może stanowić ważny powód do zwolnienia jej z tej funkcji (art. 169\$1 w związku z art. 178 \$ 2 k.r.o.).

\section{Uchwała Sądu Najwyższego z 27 października 2021 r., III CZP 43/20}

1. Wynagrodzenie prowizyjne (prowizja), stanowiące wynagrodzenie z tytułu udzielenia pożyczki, przewidziane w umowie pożyczki, do której mają zastosowanie przepisy ustawy z 12 maja 2011 r. o kredycie konsumenckim (t.j. Dz.U. z 2019 r. poz. 1083 ze zm.), nie jest świadczeniem głównym $\mathrm{w}$ rozumieniu art. $385^{1} \$ 1$ k.c.

2. Okoliczność, że pozaodsetkowe koszty kredytu konsumenckiego nie przekraczają wysokości określonej w art. 36a ust. 1 i 2 ustawy z 12 maja 2011 r. o kredycie konsumenckim, nie wyłącza oceny, czy postanowienia określające te koszty są niedozwolone (art. $385^{1} \S 1$ k.c.).

\section{Uchwała Sądu Najwyższego z 27 października 2021 r., III CZP 109/20}

Wykładnia prawa, która legła u podstaw rozstrzygnięcia w zakończonej prawomocnie sprawie, w której powód dochodził części świadczenia, nie jest objęta mocą wiążącą wyroku - w rozumieniu art. $365 \$ 1$ k.p.c. - w innej sprawie o dalszą część tego świadczenia, pomiędzy tymi samymi stronami, w tym samym stanie faktycznym i prawnym, jeśli jest rażąco sprzeczna z prawem.

\section{Uchwała Sądu Najwyższego z 26 października 2021 r., III CZP 55/20}

Nie podlega odrzuceniu zażalenie wniesione przez uczestnika postępowania przed doręczeniem mu odpisu postanowienia z uzasadnieniem, o którego sporządzenie ten uczestnik wnosił.

\section{Uchwała Sądu Najwyższego z 26 października 2021 r., III CZP 42/20}

Okoliczność, że pozaodsetkowe koszty kredytu konsumenckiego nie przekraczają wysokości określonej w art. 36a ust. 1 i 2 ustawy z 12 maja 2011 r. o kredycie konsumenckim (obecnie t.j. Dz.U. z 2019 r. poz. 1083 
ze zm.), nie wyłącza oceny, czy postanowienia określające te koszty są niedozwolone (art. $385^{1}$ \& 1 k.c.).

Uchwała Sądu Najwyższego z 7 października 2021 r., III CZP 53/20

Na postanowienie sądu drugiej instancji odrzucające skargę o wznowienie postępowania nie przysługuje zażalenie.

Uchwała Sądu Najwyższego z 7 października 2021 r., III CZP 52/20

Do rozstrzygnięcia o kosztach postępowania egzekucyjnego zawieszonego na skutek wniosku wierzyciela przed dniem 31 grudnia 2018 r., którego umorzenie $\mathrm{z}$ mocy prawa zostało stwierdzone przez komornika sądowego postanowieniem wydanym po dniu 31 grudnia 2018 r., ma zastosowanie art. 49 ust. 2 ustawy z 29 sierpnia 1997 r. o komornikach sądowych i egzekucji (t.j. Dz.U. z 2018 r. poz. 1309).

Uchwała Sądu Najwyższego z 7 października 2021 r., III CZP 51/20

Wniosek pełnomocnika z urzędu o zasądzenie na jego rzecz od Skarbu Państwa kosztów nieopłaconej pomocy prawnej nie zawiera implicite żądania zasądzenia kosztów procesu na rzecz reprezentowanej przez niego strony - jako wygrywającej (art. $98 \$ 1$ i 3 k.p.c.) - od strony przeciwnej.

\section{Sprawy z zakresu prawa karnego}

Uchwała składu siedmiu sędziów Sądu Najwyższego z 9 listopada 2021 r., I KZP 6/21

Przepis art. 632 pkt 2 k.p.k., stosowany per analogiam do orzeczenia o prawnej niedopuszczalności wydania osoby ściganej, może stanowić podstawę do zasądzenia zwrotu wydatków poniesionych przez tę osobę w związku z ustanowieniem obrońcy.

Uchwała składu siedmiu sędziów Sądu Najwyższego z 9 listopada 2021 r., I KZP 5/21

Nie popełnia przestępstwa $\mathrm{z}$ art. $233 \$$ 1a k.k. świadek składający fałszywe zeznanie $\mathrm{z}$ obawy przed grożącą mu odpowiedzialnością karną, 
jeśli - realizując prawo do obrony - zeznaje nieprawdę lub zataja prawdę, nie wyczerpując jednocześnie swoim zachowaniem znamion czynu zabronionego określonego w innym przepisie ustawy.

Sąd Najwyższy postanowił nadać uchwale moc zasady prawnej.

\section{Uchwała Sądu Najwyższego z 9 listopada 2021 r., I KZP 3/21}

Zgromadzone na rachunku bankowym środki nie są dowodem rzeczowym, o którym mowa w art. 106a ust. 8 ustawy z 29 sierpnia 1997 r. Prawo bankowe (t.j. Dz.U. z 2020 r. poz. 1896 ze zm.).

\section{Wyrok Sądu Najwyższego z 27 października 2021 r., III KK 344/21}

W drodze rozporządzenia wykonawczego do art. 46 ust. 2 i 4 ustawy z 5 grudnia 2008 r. o zapobieganiu oraz zwalczaniu zakażeń i chorób zakaźnych u ludzi Minister Zdrowia nie mógł skutecznie i w sposób prawnie wiążący ustanowić obowiązku poddania się 14-dniowej kwarantannie. Zgodnie z art. 92 ust. 1 konstytucji kompetencje dla organu, jakim jest Minister Zdrowia, do wydawania rozporządzeń obejmują wyłącznie zakres szczególowego upoważnienia zawartego w ustawie i w celu jej wykonania. Skoro w świetle obowiązującego w dniu wydania rozporządzenia przepisu ustawy określającego zakres dopuszczalnej delegacji brak było upoważnienia do ustanawiania wobec osób przekraczających granicę państwową obowiązku odbycia 14-dniowej kwarantanny, stanowiącej ze swej istoty formę ograniczenia konstytucyjnej wolności osobistej i wolności poruszania się, to takie wykroczenie poza przyznane upoważnienie stanowiło naruszenie art. 92 ust. 1 konstytucji. Tym samym wprowadzony bez upoważnienia ustawowego nakaz, jako wprost sprzeczny z zagwarantowanymi konstytucyjnie prawami do wolności oraz swobodnego poruszania się po terytorium Rzeczpospolitej Polskiej (art. 52 ust. i art. 31 ust. 1 i 3 konstytucji), nie może w sposób oczywisty tworzyć podstawy prawnej do wypełnienia blankietu normy sankcjonowanej z art. $116 \$ 1$ pkt 3 k.w. i prowadzić do ukarania na podstawie tego przepisu.

Wyrok Sądu Najwyższego z 22 października 2021 r., IV KK 247/21

Wykroczenia określonego w art. 51 \$ 1 k.w. - polegającego na wywołaniu w miejscu publicznym zgorszenia wybrykiem innym niż krzyk, hałas czy 
alarm - dopuszcza się ten, kto nagannym zachowaniem wywołuje u osób postronnych trudną do zniesienia uciążliwość, a nadto wywiera na nie zły, demoralizujący wpływ. W tym stanie rzeczy zachowanie polegające na umieszczeniu w miejscu publicznym wielkoformatowego billboardu przedstawiającego rozczłonkowany, zakrwawiony płód ludzki w celu zdyskredytowania praktyk aborcyjnych nie wypełniało znamion czynu zabronionego, o którym mowa w art. $51 \$ 1$ k.w. (art. $5 \$ 1$ pkt 2 k.p.w.).

\section{Uchwała Sądu Najwyższego z 13 października 2021 r., I KZP 1/21}

1. Przepis art. 86 ust. 13 ustawy z 1 marca 2018 r. o przeciwdziałaniu praniu pieniędzy oraz finansowaniu terroryzmu (Dz.U. z 2020 r. poz. 971) musi być interpretowany w sposób ścisły i uwzględniający gwarancyjną funkcję tego przepisu;

2. Środki zgromadzone na rachunku bankowym nie mają cech dowodu rzeczowego w rozumieniu art. 86 ust. 13 cytowanej wyżej ustawy, gdyż nie istnieją jako rzeczy, a są wyłącznie zapisami w systemie informatycznym.

\section{Sprawy z zakresu prawa pracy i ubezpieczeń społecznych}

Uchwała składu siedmiu sędziów Sądu Najwyższego z 20 stycznia 2022 r., III UZP $8 / 21$

W sprawie $\mathrm{z}$ odwołania od decyzji organu rentowego o niepodleganiu dobrowolnemu ubezpieczeniu chorobowemu (art. 11 ust. 2 ustawy z 13 października 1998 r. o systemie ubezpieczeń społecznych, t.j. Dz.U. z 2021 r. poz. 423) wartość przedmiotu zaskarżenia jest ustalana jako suma świadczeń z ubezpieczenia chorobowego za sporny okres, nie więcej niż za rok (art. 22 k.p.c.).

Uchwała składu siedmiu sędziów Sądu Najwyższego z 15 grudnia 2021 r., III UZP 7/21

Ubezpieczonemu, który pozostawał w zawodowej służbie wojskowej przed 2 stycznia 1999 r. i pobiera emeryturę wojskową wynoszącą $75 \%$ podstawy jej wymiaru obliczoną bez uwzględnienia okresów 
składkowych i nieskładkowych, z których tytułu jest uprawniony również do emerytury z Funduszu Ubezpieczeń Społecznych, wypłaca się jedno z tych świadczeń - wyższe lub wybrane przez niego (art. 95 ust. 1 i 2 ustawy z 17 grudnia 1998 r. o emeryturach i rentach z Funduszu Ubezpieczeń Społecznych, t.j. Dz.U. z 2021 r. poz. 291 ze zm. w związku z art. 7 ustawy z 10 grudnia 1993 r. o zaopatrzeniu emerytalnym żołnierzy zawodowych oraz ich rodzin, t.j. Dz.U. z 2020 r. poz. 586 ze zm.).

\section{Uchwała składu siedmiu sędziów Sądu Najwyższego z 27 października 2021 r., III PZP 1/21}

Porozumienie zawarte między inwestorem zamierzającym nabyć akcje spółki, której akcjonariuszami są pracownicy, a zakładowymi organizacjami związkowymi działającymi w tej spółce nie stanowi źródła prawa pracy jako nieoparte na ustawie (art. 9 \$ 1 k.p.).

Postanowienie Sądu Najwyższego z 20 października 2021 r., III USK 218/21 Nie może być mowy o rozbieżności w orzecznictwie wtedy, gdy wprawdzie w pewnej fazie stosowania jakiegoś przepisu przez sądy, a zwłaszcza przez Sąd Najwyższy, doszło do rozchwiania wykładni albo wyraźnych różnic jurysdykcyjnych poświadczonych odmiennymi rozstrzygnięciami, jednak następnie - po wyjaśnieniu występujących kontrowersji i uzgodnieniu stanowisk - ugruntowany został pogląd, który uzyskał przewagę i ukształtował wykładnię oraz oparte na niej orzecznictwo, niewykazujące już później odchyleń. Inaczej mówiąc, powoływanie się na rozbieżność w orzecznictwie sądów jako przyczynę kasacyjną określoną w art. $398^{9} \$ 1$ pkt 2 k.p.c. nie może dotyczyć rozbieżności, która została już usunięta przez ukształtowanie się wyraźnej, umocnionej i stabilnej linii orzeczniczej. 


\section{Bibliografia}

Postanowienie Sądu Najwyższego z 18 listopada 2021 r., V CO 209/21. Postanowienie Sądu Najwyższego z 20 października 2021 r., III USK $218 / 21$.

Uchwała Sądu Najwyższego z 28 stycznia 2022 r., III CZP 38/22.

Uchwała Sądu Najwyższego z 28 stycznia 2022 r., III CZP 35/22.

Uchwała Sądu Najwyższego z 28 stycznia 2022 r., III CZP 34/22.

Uchwała Sądu Najwyższego z 28 stycznia 2022 r., III CZP 21/22.

Uchwała Sądu Najwyższego z 28 stycznia 2022 r., III CZP 19/22.

Uchwała Sądu Najwyższego z 27 stycznia 2022 r., III CZP 36/22.

Uchwała Sądu Najwyższego z 25 stycznia 2022 r., III CZP 51/22.

Uchwała Sądu Najwyższego z 25 stycznia 2022 r., III CZP 4/22.

Uchwała Sądu Najwyższego z 21 stycznia 2022 r., III CZP 58/22.

Uchwała Sądu Najwyższego z 21 stycznia 2022 r., III CZP 37/22.

Uchwała Sądu Najwyższego z 20 stycznia 2022 r., III CZP 30/22.

Uchwała Sądu Najwyższego z 20 stycznia 2022 r., III CZP 23/22.

Uchwała Sądu Najwyższego z 20 stycznia 2022 r., III CZP 17/22. Uchwała Sądu Najwyższego z 20 stycznia 2022 r., III CZP 9/22. Uchwała Sądu Najwyższego z 20 stycznia 2022 r., III CZP 8/22. Uchwała Sądu Najwyższego z 13 stycznia 2022 r., III CZP 65/22. Uchwała Sądu Najwyższego z 13 stycznia 2022 r., III CZP 61/22. Uchwała Sądu Najwyższego z 13 stycznia 2022 r., III CZP 14/22. Uchwała Sądu Najwyższego z 12 stycznia 2022 r., III CZP 78/22. Uchwała Sądu Najwyższego z 12 stycznia 2022 r., III CZP 67/22. Uchwała Sądu Najwyższego z 12 stycznia 2022 r., III CZP 60/22. Uchwała Sądu Najwyższego z 12 stycznia 2022 r., III CZP 24/22. Uchwała Sądu Najwyższego z 9 grudnia 2021 r., III CZP 112/20 Uchwała Sądu Najwyższego z 9 grudnia 2021 r., III CZP 103/20. Uchwała Sądu Najwyższego z 9 grudnia 2021 r., III CZP 96/20. Uchwała Sądu Najwyższego z 9 grudnia 2021 r., III CZP 85/20. Uchwała Sądu Najwyższego z 9 grudnia 2021 r., III CZP 49/21. Uchwała Sądu Najwyższego z 9 grudnia 2021 r., III CZP 26/21. Uchwała Sądu Najwyższego z 9 grudnia 2021 r., III CZP 21/21. Uchwała Sądu Najwyższego z 9 grudnia 2021 r., III CZP 16/21. 
Uchwała Sądu Najwyższego z 7 grudnia 2021 r., III CZP 87/20. Uchwała Sądu Najwyższego z 7 grudnia 2021 r., III CZP 67/20. Uchwała Sądu Najwyższego z 3 grudnia 2021 r., III CZP 90/20. Uchwała Sądu Najwyższego z 3 grudnia 2021 r., III CZP 84/20. Uchwała Sądu Najwyższego z 24 listopada 2021 r., III CZP 80/20. Uchwała Sądu Najwyższego z 18 listopada 2021 r., III CZP 77/20. Uchwała Sądu Najwyższego z 16 listopada 2021 r., III CZP 76/20. Uchwała Sądu Najwyższego z 9 listopada 2021 r., III CZP 70/20. Uchwała Sądu Najwyższego z 9 listopada 2021 r., III CZP 69/20. Uchwała Sądu Najwyższego z 9 listopada 2021 r., I KZP 3/21. Uchwała Sądu Najwyższego z 5 listopada 2021 r., III CZP 68/20. Uchwała Sądu Najwyższego z 29 października 2021 r., III CZP 60/20. Uchwała Sądu Najwyższego z 27 października 2021 r., III CZP 109/20. Uchwała Sądu Najwyższego z 27 października 2021 r., III CZP 56/20. Uchwała Sądu Najwyższego z 27 października 2021 r., III CZP 54/20. Uchwała Sądu Najwyższego z 27 października 2021 r., III CZP 43/20. Uchwała Sądu Najwyższego z 26 października 2021 r., III CZP 55/20. Uchwała Sądu Najwyższego z 26 października 2021 r., III CZP 42/20. Uchwała Sądu Najwyższego z 13 października 2021 r., I KZP 1/21. Uchwała Sądu Najwyższego z 7 października 2021 r., III CZP 53/20. Uchwała Sądu Najwyższego z 7 października 2021 r., III CZP 52/20. Uchwała Sądu Najwyższego z 7 października 2021 r., III CZP 51/20. Uchwała składu siedmiu sędziów Sądu Najwyższego z 20 stycznia 2022 r., III UZP 8/21.

Uchwała składu siedmiu sędziów Sądu Najwyższego z 14 stycznia 2022 r., III CZP 7/22.

Uchwała składu siedmiu sędziów Sądu Najwyższego z 16 grudnia 2021 r., III CZP 99/20.

Uchwała składu siedmiu sędziów Sądu Najwyższego z 16 grudnia 2021 r., III CZP 98/20.

Uchwała składu siedmiu sędziów Sądu Najwyższego z 15 grudnia 2021 r., III UZP 7/21.

Uchwała składu siedmiu sędziów Sądu Najwyższego z 8 grudnia 2021 r., III CZP 83/20.

Uchwała składu siedmiu sędziów Sądu Najwyższego z 9 listopada 2021 r., I KZP 6/21. 
Uchwała składu siedmiu sędziów Sądu Najwyższego z 9 listopada 2021 r., I KZP 5/21.

Uchwała składu siedmiu sędziów Sądu Najwyższego z 27 października 2021 r., III PZP 1/21.

Uchwała składu siedmiu sędziów Sądu Najwyższego z 22 października 2021 r., III CZP 78/20.

Wyrok Sądu Najwyższego z 27 października 2021 r., III KK 344/21.

Wyrok Sądu Najwyższego z 22 października 2021 r., IV KK 247/21. 